\title{
Lusioersily
}

\section{Glucoregulatory, endocrine and morphological effects of [P5K]hymenochirin-1B in mice with diet-induced glucose intolerance and insulin resistance.}

Owolabi, BO., Ojo, OO., Srinivasan, DK., Conlon, JM., Flatt, P., \& Abdel-Wahab, Y. (2016). Glucoregulatory, endocrine and morphological effects of [P5K]hymenochirin-1B in mice with diet-induced glucose intolerance and insulin resistance. Naunyn-Schmiedeberg's Archives of Pharmacology, 389, 769-781. https://doi.org/10.1007/s00210-016-1243-5

Link to publication record in Ulster University Research Portal

Published in:

Naunyn-Schmiedeberg's Archives of Pharmacology

Publication Status:

Published (in print/issue): 12/04/2016

DOI:

10.1007/s00210-016-1243-5

\section{Document Version}

Author Accepted version

\section{General rights}

Copyright for the publications made accessible via Ulster University's Research Portal is retained by the author(s) and / or other copyright owners and it is a condition of accessing these publications that users recognise and abide by the legal requirements associated with these rights.

\section{Take down policy}

The Research Portal is Ulster University's institutional repository that provides access to Ulster's research outputs. Every effort has been made to ensure that content in the Research Portal does not infringe any person's rights, or applicable UK laws. If you discover content in the Research Portal that you believe breaches copyright or violates any law, please contact pure-support@ulster.ac.uk. 


\section{Glucoregulatory, endocrine and morphological effects of $\left[\mathrm{P}_{5} \mathrm{~K}\right]$ hymenochirin-1B in mice with diet-induced glucose intolerance and insulin resistance}

\section{AQ1}

Bosede O. Owolabi 1

Opeolu O. Ojo 1,z

Dinesh K. Srinivasan 1

J. Michael Conlon 1,*

Emailm.conlon@ulster.ac.uk

Peter R. Flatt 1

Yasser H. A. Abdel-Wahab 1

1 SAAD Centre for Pharmacy and Diabetes, School of Biomedical

Sciences, University of Ulster, Coleraine, BT52 1SA UK

zPresent address: School of Health, Sport and Bioscience, University of East London, Stratford, E15 4LZ UK

\section{Abstract}

The frog skin host-defence peptide hymenochirin-1B has been shown to stimulate insulin release in vitro from isolated pancreatic islets and BRINBD11 clonal $\beta$-cells. This study examines the effects of 28-day administration of a more potent analogue [P5K]hymenochirin-1B ([P5K]hym-1B) $\left(75 \mathrm{nmol} \cdot \mathrm{kg}^{-1}\right.$ body weight) to high-fat-fed mice with 
obesity, glucose intolerance and insulin resistance. Treatment with [P5K]hym-1B significantly decreased plasma glucose concentrations and improved glucose tolerance, insulin secretion, insulin sensitivity and increased the magnitude of the incretin effect (difference in response to oral vs intraperitoneal glucose loads). Responses to established insulin secretagogues were greater in islets isolated from treated animals compared with saline-treated controls. [P5K]hym-1B administration significantly decreased total islet area and $\beta$ - and $\alpha$-cell areas, and resulted in lower concentrations of circulating triglycerides and plasma and pancreatic glucagon. Peptide treatment had no effect on food intake, body weight, indirect calorimetry or circulating concentrations of amylase and marker enzymes of liver and kidney function. RT-PCR demonstrated that the Insr (insulin receptor) gene and genes involved in insulin signalling (Slc2a4, Irs 1, Pik3ca, Akt1 and Pkd1) were significantly up-regulated in skeletal muscle from animals treated with [P5K]hym-1B. Expression of the Glp $1 r$ (GLP-1 receptor) and Gipr (GIP receptor) genes was significantly elevated in islets from peptide-treated mice. These data suggest that [P5K]hym-1B shows potential for development into an agent for treating patients with type 2 diabetes.

\section{Keywords}

Hymenochrin-1B

Type 2 diabetes

Insulin resistance

Glucose tolerance

Insulin secretion

\section{Introduction}

A recent comprehensive global survey of levels and trends in disease has demonstrated a worldwide increase in the incidence of type 2 diabetes (T2D) (Global Burden of Disease Study 2013 2015). Obesity, usually accompanied by hyperinsulinemia and insulin resistance, is an important determinant in the aetiology and progression of the disease (Weyer et al. 2001). Evidence supports a link between a high-fat diet, particularly one rich in saturated fat, 
and insulin resistance (Marshall and Bessesen 2002). In the gut, lipid ingestion initiates feedback mechanisms to regulate of glucose and lipid metabolism. However, these lipid-sensing pathways are compromised in insulin resistance. Increased production of adipocyte-derived molecules, such as resistin, non-esterified fatty acids and glycerol, in obesity promotes insulin resistance along with increased synthesis of the pro-inflammatory cytokines, tumour necrosis factor $\alpha$, interleukin- 6 and monocyte chemo-attractant protein (Ye 2013). Elevated levels of triglyceride-derived products such as diacylglycerol, fatty acyl-coenzyme A and ceramides initiate a kinase cascade which results in phosphorylation of serine/threonine sites on insulin receptor substrates (IRS) 1and 2. Phosphorylation decreases the ability of IRS to stimulate phosphoinositol-3-kinase activity resulting ultimately in reduced glucose uptake (Kahn et al. 2006; Cerf 2013). In addition, it has been proposed that increased consumption of dietary fat promotes islet amyloid formation leading to impaired $\beta$-cell function (Hull et al. 2003).

In addition to extensively utilized compounds that stimulate insulin secretion and suppress hepatic glucose production such as metformin and sulphonylureas, newer approaches to the pharmacological treatment of patients with T2D have been developed. These include agents that primarily stimulate glucose-dependent insulin secretion, e.g. long-acting GLP-1 analogues and dipeptidyl peptidase-4 inhibitors, drugs that inhibit glucose absorption, e.g. $\alpha$-glucosidase inhibitors, or stimulate glucose excretion into urine, e.g. inhibitors of the $\mathrm{Na}^{+}$glucose cotransporter SGLT2, and agents that improve insulin sensitivity by acting at peroxisome proliferator-activated receptors, e.g. thiazolidinediones [reviewed in (Turner et al. 2016)]. There is growing need for new therapeutic agents as currently available drugs have only limited success in tackling the major metabolic defects associated with the disease and may display adverse side-effects. In particular, it is important to develop treatment regimens that are able to ameliorate the insulin resistance and reverse the islet abnormalities that occur in these patients. The high-fat-fed mouse exhibits obesity, glucose intolerance and insulin resistance and so is a useful model for understanding the effect of an energyrich high-fat western diet on the aetiology and progression of type 2 diabetes (Winzell and Ahren 2004). Multi-functional host-defence peptides present in skin secretions of several species of frogs, which were usually first identified 
on the basis of their antimicrobial activity, have subsequently shown potential for development in therapeutically valuable anti-diabetic agents [reviewed in (Conlon et al. 2014)]. In particular, previous studies have shown that administration of the frog skin peptides, magainin-AM2 (Ojo et al. 2015a), tigerinin-1R (Ojo et al. 2015b) and CPF-SE1 (Srinivasan et al. 2015) to high-fat-fed mice for up to 28 days improves glucose tolerance, insulin sensitivity and islet $\beta$-cell secretory responsiveness. However, the molecular mechanisms by which the peptides exert their beneficial effects are poorly understood.

Hymenochirin-1B (Hym-1B) was first isolated from skin secretions of the Congo dwarf clawed frog Hymenochirus boettgeri from the family Pipidae (Mechkarska et al. 2012) and the peptide has been shown to display broadspectrum antimicrobial activities (Mechkarska et al. 2013) and is cytotoxic to a range of human tumour cells (Attoub et al. 2013). Hym-1b stimulates in vitro insulin release from BRIN-BD11 clonal beta cells and mouse pancreatic islets and a recent structure-activity study has shown that the [P5K] analogue shows increased potency and efficacy compared to the native peptide and low haemolytic activity (Owolabi et al. 2016). The present investigation reports the effects of 28-day administration of [P5K]Hym-1B on glycaemic control and insulin release, insulin sensitivity, plasma lipid profile and energy balance in high-fat-fed mice. In addition, insight into the mechanism of action of the peptide has been gained by investigating the effects of peptide treatment on glucagon concentrations, islet cell morphology and expression of selected genes that are important in mediating insulin release in islets and insulin action in skeletal muscle.

\section{Materials and methods}

\section{Experimental animals}

High-fat-fed mice, with clear manifestations of obesity, glucose intolerance and insulin resistance, and age-matched lean mice were used in the study. Adult (8-week-old), male, National Institutes of Health Swiss mice (Harlan Ltd., UK) mice were housed separately in an air-conditioned room $\left(22 \pm 2{ }^{\circ} \mathrm{C}\right)$ with relative humidity of $51 \pm 5 \%$ and a 12-h light/12-h dark cycle. Animals were maintained on a high-fat diet (45\% kcal fat, $20 \% \mathrm{kcal}$ 
protein and $35 \%$ kcal carbohydrate) (Dietex International Ltd., Witham, UK) or on a standard rodent pellet diet (Trouw Nutrition, Northwich, UK) for 3 months before the experiment. All animal experiments were carried out in accordance with the UK Animals (Scientific Procedures) Act 1986 and EU Directive 2010/63EU for animal experiments and approved by Ulster University Animal Ethics Review Committee. All necessary steps were taken to ameliorate any potential animal suffering.

\section{$\left[\mathrm{P}_{5} \mathrm{~K}\right]$ hym-1B administration}

[P5K]hym-1B (IKLSKETKDNLKKVLKGAIKGAIAVAKMV.NH ${ }_{2}$ ) was obtained in crude form from GL Biochem Ltd. (Shanghai, China) and purified to near homogeneity ( $>98 \%$ purity) as previously described (Owolabi et al. 2016). Animals received twice daily intraperitoneal injections (0900 and 2100 hours) of either $0.9 \%$ saline vehicle (lean control group and high-fatfed control group) or [P5K]hym-1B (75 nmol $\cdot \mathrm{kg}^{-1} \mathrm{~g}$ body weight) for 28 days. This injection dose was determined on the basis of pilot experiments assessing the acute effects of doses of 50,75 and $150 \mathrm{nmol} \cdot \mathrm{kg}^{-1}$ body weight on glycaemic control. Energy intake, bodyweight, non-fasting blood glucose and plasma insulin concentrations were measured $72 \mathrm{~h}$ before and every 3 days throughout the study period. Other tests were conducted after 28-days treatment when terminal samples were collected and analysed as described below.

\section{Effects on glucose tolerance and insulin sensitivity}

Glucose tolerance tests $\left(18 \mathrm{mmol} \cdot \mathrm{kg}^{-1}\right.$ body weight, intraperitoneal and oral) were carried out after 28 days in overnight fasted lean mice and in high-fatfed mice treated with either saline or [P5K]hym-1B as previously described (Ojo et al. 2015a, b). Blood samples were collected from a tail vein and blood glucose were determined using an Ascencia Contour Blood Glucose Metre (Bayer, Newbury, UK). Plasma insulin concentrations were measured by radioimmunoassay (Flatt and Bailey 1981). Insulin sensitivity tests ( $25 \mathrm{U} \cdot \mathrm{kg}^{-1}$ body weight) were carried out after 28 days in mice fed ad libitum as previously described (Srinivasan et al. 2015). All other samples were collected using mice fed ad libitum. Insulin resistance (HOMA IR) was determined using homeostatic model assessment (HOMA) as previously 
described (Martin et al. 2012). HOMA IR was calculated using the formula: HOMA IR $=$ fasting plasma insulin $\times$ fasting plasma glucose $/ 22.5$. Tests were performed at 1000 hours without prior injection at [P5K]hym-1B at 0900 hours.

\section{Effects on energy intake and body composition}

Indirect calorimetry and energy expenditure in the treated and control groups were determined after 28 days of peptide treatment using the Comprehensive Laboratory Animal Monitoring System (CLAMS) metabolic chambers (Columbus Instruments, Columbus, OH, USA). Terminal analysis involved measurement of total and body fat mass, together with bone mineral density and bone mineral content by DXA scanning (Piximus Densitometer, Fitchburg, WI, USA). RER was calculated by dividing $\mathrm{VCO}_{2}$ by $\mathrm{VO}_{2}$ Energy expenditure (EE) was calculated using the equation $\mathrm{EE}=3.815+1.232 \times \mathrm{RER}) \times \mathrm{VO}_{2}$.

\section{Insulin-release studies from isolated mouse islets}

Effects of [P5K]hym-1B treatment on $\beta$-cell function was assessed by measurement of insulin secretory responses to known secretagogues in vitro using pancreatic islets from 28-day-treated and control animals. Islets, isolated by collagenase digestion (Goto et al. 1985), were cultured overnight in RPMI 1640 medium prior to a 40-min pre-incubation (5-10 islets per $500 \mu \mathrm{l})$ at $37^{\circ} \mathrm{C}$ in Krebs-Ringer bicarbonate (KRB) buffer (composition in millimolar: $115 \mathrm{NaCl}, 4.7 \mathrm{KCl}, 1.28 \mathrm{CaCl}_{2}, 1.2 \mathrm{KH}_{2} \mathrm{PO}_{4}, 1.2 \mathrm{MgSO}_{4}, 20$ HEPES, $25 \mathrm{NaHCO}_{3}$; pH 7.4) supplemented with $0.1 \%$ bovine serum albumin and $1.4 \mathrm{mM}$ glucose. After this period, islets were incubated for $1 \mathrm{~h}$ in KRB buffer with 1.4 or $16.7 \mathrm{mM}$ glucose and $1 \mu \mathrm{M}$ glucagon-like peptide1 (GLP-1), $1 \mu \mathrm{M}$ glucose-dependent insulinotropic peptide (GIP), $10 \mathrm{mM}$ alanine, $10 \mathrm{mM}$ arginine or $30 \mathrm{mM} \mathrm{KCl}$ as indicated in Fig. 5. Insulin release was measured by radioimmunoassay and results are expressed as a percentage of total insulin content of the islets.

\section{Biochemical analyses}

Pancreatic tissues were harvested from 28-day treated mice and homogenized in $20 \mathrm{mM}$ Tris- $\mathrm{HCl}, 150 \mathrm{mM} \mathrm{NaCl}, 1 \mathrm{mM}$ EDTA, $1 \mathrm{mM}$ EGTA and $0.5 \%$ 
Triton X 100; pH 7.5 as previously described (Srinivasan et al. 2015).

Pancreatic insulin content was measured by radioimmunoassay. Protein concentrations were determined using Bradford reagent (Sigma, Dorset, UK). Effects of treatment on renal and liver function were assessed by measurement of plasma levels of creatinine, alanine transaminase (ALT), aspartic acid transaminase (AST) and alkaline phosphatase (ALP) using assay kits supplied by Randox Laboratories, Antrim, U.K.). Plasma triglyceride and total cholesterol, low-density lipoprotein (LDL) and high-density lipoprotein (HDL) concentrations were measured using an I-lab 650 clinical chemistry instrument (Instrumentation Laboratory, Warrington, UK). The assay kit for cholesterol was obtained from Randox Laboratories. LDL cholesterol was estimated using the Friedewald equation as described (Johnson et al. 1997). Plasma and pancreatic glucagon concentrations were measured using an ELISA kit (EMD, Millipore, Watford, UK). Serum amylase concentration was determined using an amylase assay kit from Abcam (Cambridge, UK). In all cases, the manufacturers' recommended protocols were followed.

\section{Immunohistochemistry}

Pancreatic tissues obtained from treated and untreated animals were fixed in $4 \%$ paraformaldehyde for $48 \mathrm{~h}$ at $4{ }^{\circ} \mathrm{C}$ and embedded in paraffin (Moffett et al. 2013, 2014). Specimens were sectioned at $8 \mu \mathrm{m}$ thickness using a microtome (Shandon finesse 325, Thermo scientific, UK) and selected at an interval of 10 sections. Sections were de-waxed in xylene (Sigma Aldrich, UK) and rehydrated by incubation in graded ethanol concentrations. Antigen retrieval was performed using citrate buffer $\left(\mathrm{pH} \mathrm{6.0)}\right.$ at $94{ }^{\circ} \mathrm{C}$ for $20 \mathrm{~min}$. The sections were blocked in $10 \%$ BSA and incubated with primary antibodies, mouse monoclonal anti-insulin (ab, 1:600; Abcam) or guinea-pig antiglucagon (1:400; raised in-house) overnight at $4{ }^{\circ} \mathrm{C}$. Sections were incubated with secondary antibodies (goat anti-guinea pig IgG, Alexa Fluor 488 conjugate 1:400; Alexa Fluor 594 goat anti-mouse IgG, 1:400) for $45 \mathrm{~min}$ at $37^{\circ} \mathrm{C}$. Slides were washed in PBS and mounted in anti-fade mounting medium. Slides were viewed with fluorescence microscope (Olympus system microscope, model BX51) at $\times 10$ and $\times 20$ magnification with either a FITC filter $(488 \mathrm{~nm})$ or a TRITC filter $(594 \mathrm{~nm})$ and photographed with the DP70 camera adapter system. Antibodies used were highly specific and showed no cross-reactivity with other pancreatic hormones. Islet number, islet area, $\beta$ - 
cell area and $\alpha$-cell area were analysed using $C$ ell ${ }^{\Lambda} \mathrm{F}$ image analysis software (Olympus Soft Imaging Solutions GmbH, Münster, Germany). For analysis of islet size distribution, islets were classified as small, medium and large. Islets were designated 'small' if they were less than $10,000 \mu \mathrm{m}^{2}$, 'medium' if between 10,000 and 25,000 $\mu^{2}$ and 'large' if greater than $25,000 \mu^{2}$.

\section{Gene expression studies}

mRNA was extracted from skeletal muscle and islets using TriPure isolation reagent following the manufacturer's recommended procedure. Conversion of mRNAs (1-3 $\mu \mathrm{g})$ to cDNAs was performed using SuperScript ${ }^{\mathrm{TM}}$ II Reverse Transcriptase (Invitrogen Life Technologies, Carlsbad, CA, U.S.A.) (Moffett et al. 2013 ). Genes were amplified by real time reverse transcription polymerase chain reaction (RT-PCR) using an Opticon real-time PCR system with attached Bio-Rad CFX96 software and a Quantifast SYBR green RTPCR kit (Qiagen Ltd., Manchester, U.K.) according to the manufacturer's recommended procedure with slight modifications. The reaction mixture comprised Quantifast SYBR green PCR mix ( $9 \mu 1)$, appropriate forward and reverse primers $(1 \mu \mathrm{l}$ each), cDNA $(1 \mu \mathrm{l})$ and RNase-free water $(6 \mu \mathrm{l})$. PCR conditions for all amplification were set as initial denaturation $95{ }^{\circ} \mathrm{C}$ for $5 \mathrm{~min}$, final denaturation $95^{\circ} \mathrm{C}$ for $30 \mathrm{~s}$, annealing temp $58^{\circ} \mathrm{C}$ for $30 \mathrm{~s}$ and final extension at $72{ }^{\circ} \mathrm{C}$ for $30 \mathrm{~s}$. $\beta$-actin (ActB) was used as a positive control for each PCR experiment and results were analysed using the $\Delta \Delta \mathrm{Ct}$ method, with mRNA expression normalized to ACTB. The primers used for the experiments are shown in Table 1 .

\section{Table 1}

List of genes studied and their primer sequences

\begin{tabular}{|l|l|l}
\cline { 3 - 3 } Gene & \multicolumn{1}{|c|}{ Common name } & \multicolumn{1}{c}{ Primer sequence } \\
Insr & Insulin receptor & $\begin{array}{l}\text { F-GCA GGA AAT GGC TCC } \\
\text { TGG AC } \\
\text { R-GGG GTC CAA TGA TAA } \\
\text { TTT TGG CAA T }\end{array}$ \\
\hline Gipr & $\begin{array}{l}\text { Gastric inhibitory polypeptide } \\
\text { receptor }\end{array}$ & $\begin{array}{l}\text { F- TGC CCC GAC TAC CGA CTA } \\
\text { AG } \\
\text { R- GCC TTC AAC CTG TTC CTC } \\
\text { CG }\end{array}$ \\
\hline & & F- GCT GAG GGT CTC TGG CTA \\
\hline
\end{tabular}




\begin{tabular}{|c|c|c|}
\hline Glplr & Glucagon-1 like peptide receptor & $\begin{array}{l}\text { CA } \\
\text { R- GGG ACA GGA GCT GTT } \\
\text { CCT CA }\end{array}$ \\
\hline $\operatorname{Irs} 1$ & Insulin receptor substrate 1 & $\begin{array}{l}\text { F- AGG ACC TCA CGT CTT CCT } \\
\text { CTT } \\
\text { R- TTC CGG TGT CAC AGT GCT } \\
\text { TTC }\end{array}$ \\
\hline Ptbl & Protein phosphatase 1B & $\begin{array}{l}\text { F- TCG CCT GCG CAT TTG TAC } \\
\text { TC } \\
\text { R- TGA GTT TTC CAG TGC CCC } \\
\text { AAA }\end{array}$ \\
\hline Pik3ca & $\begin{array}{l}\text { Phosphatidylinositol 3-kinase, } \\
\text { catalytic subunit } \alpha\end{array}$ & $\begin{array}{l}\text { F- ACA GAG ACA GAG CAC } \\
\text { GAT CCA } \\
\text { R- TCC ACG TGC TGT GAG GTT } \\
\text { TC }\end{array}$ \\
\hline$P d k 1$ & $\begin{array}{l}\text { 3-phosphoinositide dependent } \\
\text { protein kinase } 1\end{array}$ & $\begin{array}{l}\text { F- TGG GTC CAG TGG ATA AGC } \\
\text { GAA } \\
\text { R- CCG GTA ATT ACA TCG TGT } \\
\text { GGA CAA }\end{array}$ \\
\hline Akt1 & Protein kinase $\mathrm{B}$ & $\begin{array}{l}\text { F- GCC GCC TGA TCA AGT TCT } \\
\text { CC } \\
\text { R- CAG CGC ATC CGA GAA } \\
\text { ACA AAA C }\end{array}$ \\
\hline Slc $2 a 4$ & GLUT4 glucose transporter & $\begin{array}{l}\text { F- ACT AGA TCC CGG AGA } \\
\text { GCC TGG } \\
\text { R- TGG AAA CCC GAC GGC } \\
\text { ATC TT }\end{array}$ \\
\hline
\end{tabular}

\section{Statistical analysis}

Data were compared using unpaired Student's t test (non-parametric, with two-tailed $P$ values and $95 \%$ confidence interval) and one-way ANOVA with Bonferroni post hoc test wherever applicable. Area under the curve (AUC) analysis was carried out using the trapezoidal rule with baseline correction. Values were presented as means \pm S.E.M. The significance levels were set at $P<0.05, P<0.01$ and $P<0.001$.

\section{Results}

Effects of [P5K]hym-1B on food intake, body weight, nonfasting blood glucose and plasma insulin concentrations 
Following 28-day administration of the peptide, body weight (Fig. 1 a, b), food intake (Fig. 1 c), non-fasting blood glucose (Fig. 1d, e) and non-fasting plasma insulin (Fig. $1 \mathrm{f}, \mathrm{g}$ ) concentrations were significantly greater in animals fed a high-fat diet compared with the lean controls. However, no difference was observed in body weight and food intake between animals treated with [P5K]hym-IB and the untreated high-fat-fed controls.

Administration of $[\mathrm{P} 5 \mathrm{~K}]$ hym-1B resulted in a significant $(P<0.05)$ reduction in blood glucose concentrations (Fig. 1 d, e) by day 24 but plasma insulin concentrations were not significantly different at any time point (Fig. $1 \mathrm{f}, \mathrm{g}$ ).

\section{Fig. 1}

Effects of twice daily administration of [P5K]hym-1B on $\mathbf{a}, \mathbf{b}$ body weight), $\mathbf{c}$ food intake, $\mathbf{d}$, e blood glucose, $\mathbf{f}, \mathbf{g}$ plasma insulin and $\mathbf{h}, \mathbf{i}$ body fat in high-fatfed mice. For panels $-\mathbf{a}-\mathbf{g}$, measurements were taken 3 days before and at $72-\mathrm{h}$ interval throughout the 28-day treatment period. For panels $\mathrm{h}$ and $\mathrm{i}$, body fat was measured by DEXA scanning at the end of the study. Values are means \pm S.E.M. $(n=6)$. Integrated responses (area under the curve are shown. ${ }^{*} P<0.01, * * * P<0.001$ compared to lean control mice and ${ }^{\Delta} P<0.05$, ${ }^{\Delta \Delta} P<0.05$ compared to high-fat-fed control mice 

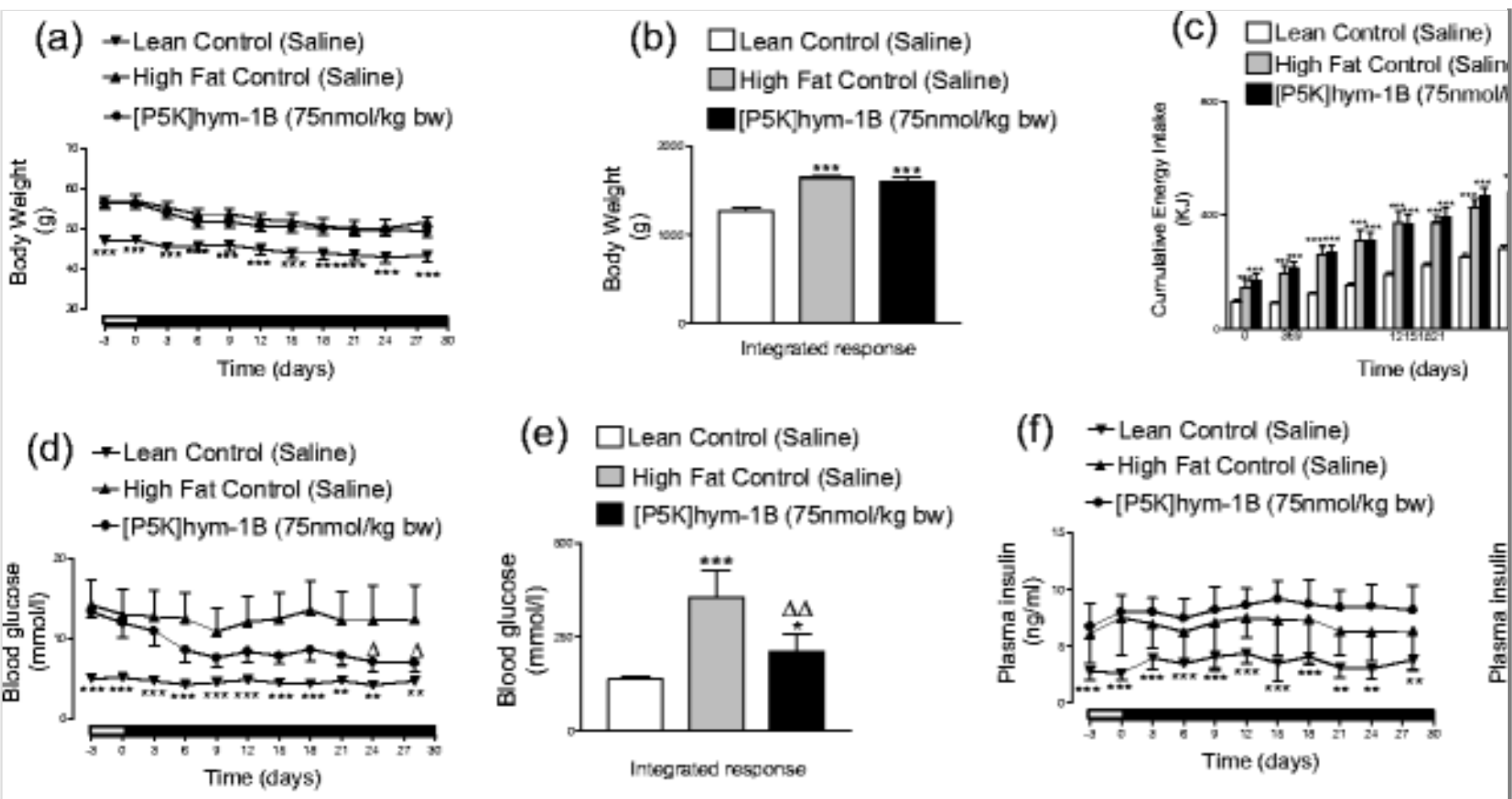

(h)

$\square$ Lean Control (Saline)

$\square$ High Fat Control (Saline)

(i) $\square$ Lean Control (Saline)

[P5K]hym-1B (75nmol/kg bw)
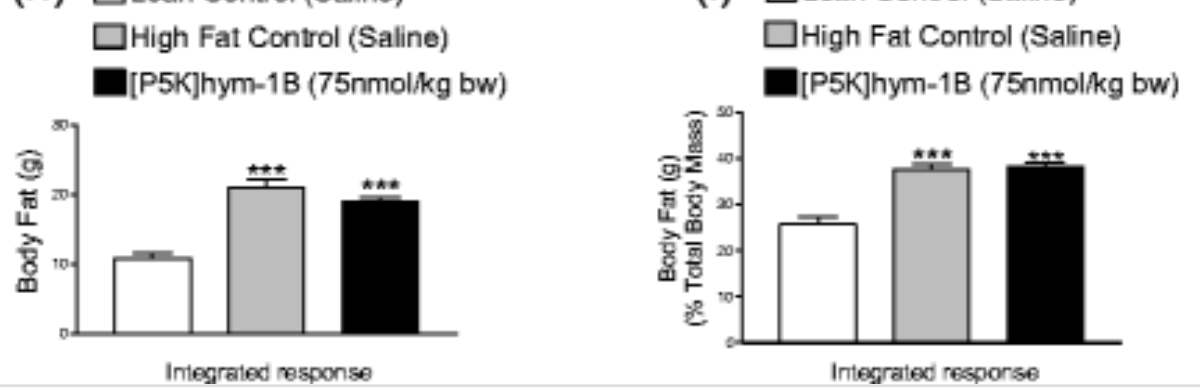

\section{Effects of $\left[\mathrm{P}_{5} \mathrm{~K}\right]$ hym-1B administration on body composition and energy expenditure}

As expected, a high-fat diet significantly $(31 \%, P<0.001)$ increased body fat compared to standard rodent diet but there was no significant difference between the body fat content in mice treated with [P5K]hym-1B and salinetreated control mice fed a high-fat diet (Fig. 1 h, i). No differences were observed in bone mineral density, bone mineral content, bone area and lean body mass between the three groups of mice (data not shown). [P5K]hym-1B treatment had no effect on oxygen consumption and carbon dioxide production and these parameters were not significantly different in the three groups. Respiratory exchange ratio (RER) was significantly $(P<0.001)$ lower in both high-fat-fed groups compared to lean controls but there was no difference in RER between the high-fat-fed [P5K]hym-1B-treated and untreated groups. The high-fat-fed animals showed a significant $(P<0.01)$ 
increase in energy expenditure (EE) but [P5K]hym-1B treatment had no effect (data not shown).

Effect of $\left[\mathrm{P}_{5} \mathrm{~K}\right] \mathrm{hym}-1 \mathrm{~B}$ on glucose tolerance, HOMA IR and insulin sensitivity

After an intraperitoneal glucose load, high-fat-fed mice exhibited impaired glucose tolerance (Fig. 2a, 2b) and significantly $(P<0.01)$ enhanced insulin response to glucose (Fig. $2 \mathrm{c}, 2 \mathrm{~d}$ ) compared with the lean control group. A comparison of glucose tolerance (Fig. 2 e, f) and insulin response (Fig. 2 g, h) in high-fat-fed and lean mice after the same glucose load administered orally is shown. Both glucose tolerance and glucose-induced insulin secretion were significantly enhanced $(P<0.05)$ following either an intraperitoneal or oral glucose load in mice that received [P5K] hym-1B compared to high-fat-fed animals injected with saline. Comparing the integrated responses (area under curve, AUC) to intraperitoneal and oral glucose challenges, a significantly greater increase in plasma insulin with a concomitant reduction in blood glucose was observed following an oral glucose load compared to intraperitoneal injection (Fig 3 ). The impaired incretin effect in high-fat-fed mice was reversed by [P5K]hym-1B treatment. Indeed, the responses of these mice were significantly $(P<0.05)$ superior to those of lean control mice. [P5K]hym-1B administration also improved insulin sensitivity (Fig. 4a, b) and produced a significant $(P<0.05)$ reduction in HOMA IR insulin resistance compared with saline-treated high-fat-fed mice (Fig $4 \mathrm{c}$ ).

\section{Fig. 2}

Glucose tolerance and plasma insulin following intraperitoneal and oral administration of glucose in high-fat-fed mice treated with [P5K]hym-1B. Blood samples were collected before and after intraperitoneal (panels a-d) and oral (panels $\mathbf{e}-\mathbf{h}$ ) administration of glucose (18 mmol/ $\mathrm{kg}$ body weight) in lean and high-fat-fed control mice and in mice treated with $[\mathrm{P} 5 \mathrm{~K}] \mathrm{hym}-1 \mathrm{~B}$ for 28 days. Values are means \pm S.E.M. $(n=8)$. Integrated responses (area under the curve) are shown in panels $\mathbf{b}$, d, f and $\mathbf{h} . * * P<0.01, * * * P<0.001$ compared to lean control mice. ${ }^{\Delta} P<0.05,{ }^{\Delta \Delta} P<0.01$ compared to high-fat-fed control mice 
Intraperitoneal Glucose Administration

(a) *Lean Control (Saline)

- High Fat Control (Saline)

$\rightarrow[$ P5K]hym-1B (75nmollkg bw)

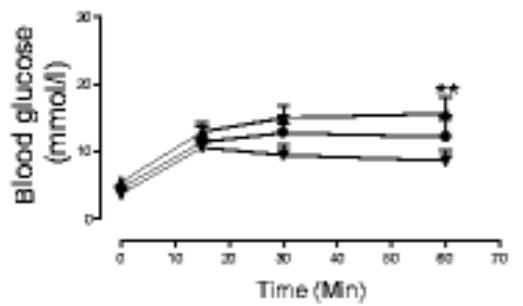

Oral Glucose Administration

(e)

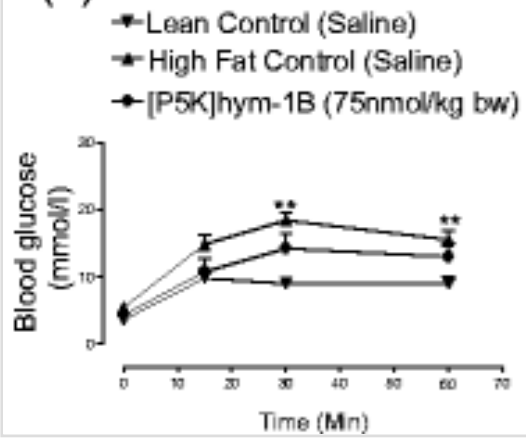

(b)

$\square$ Lean Control (Saline)

$\square$ High Fat Control (Saline)

[P5K]hym-1B (75nmol/kg bw)

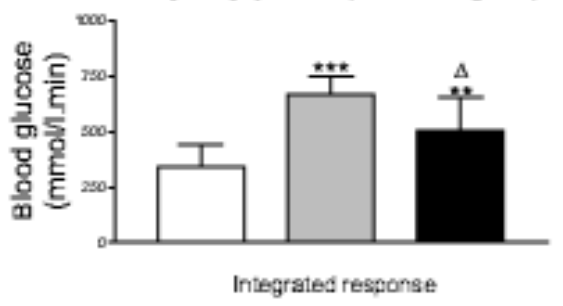

(f)
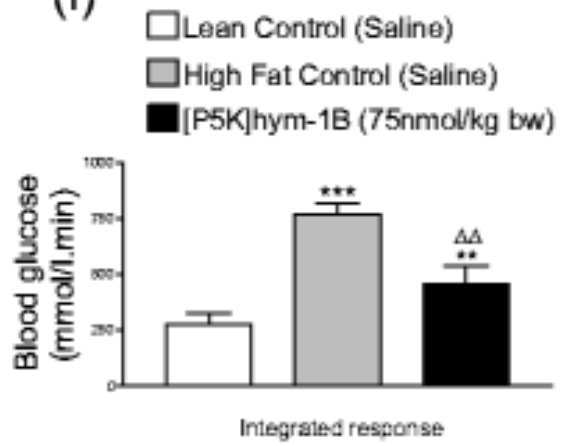

(c) *-Lean Control (Saline)

-High Fat Control (Saline)

$\bullet-[\mathrm{P5K}] \mathrm{hym}-1 \mathrm{~B}(75 \mathrm{nmol} / \mathrm{kg}$ bw)

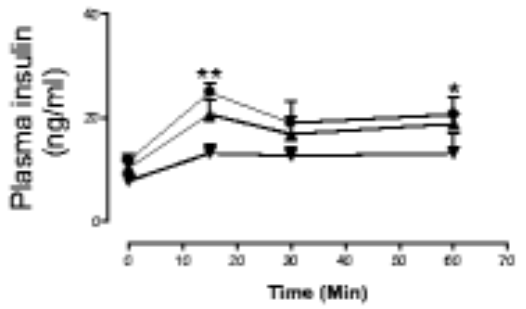

(g)

*-Lean Control (Saline)

-High Fat Control (Saline)

$\rightarrow[$ P5K]hym-1B (75nmol/kg bw)

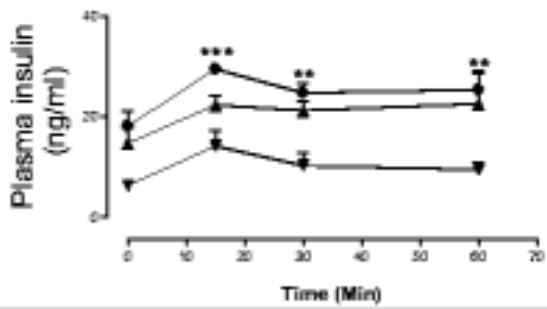

\section{Fig. 3}

Comparison of the incretin effect of intraperitoneal and oral administration of glucose in lean, high-fat-fed and [P5K]hym-1B-treated mice after 28 days. Intraperitoneal (IGTT) and oral (OGTT) glucose tolerance tests were carried out on overnight-fasted mice. Values are means \pm S.E.M. $(n=8)$. Panels a and b show the differences in integrated response (area under the curve) for IGTT and OGTT for glucose and insulin respectively. $* P<0.05, * * * P<0.001$ compared to lean control. ${ }^{\Delta \Delta} P<0.01,{ }^{\Delta \Delta \Delta} P<0.001$ compared with high-fat-fed control mice

\section{Blood Glucose}

(a)

$\square$ Lean Control (Saline)

$\square$ High Fat Control (Saline)

[P5K]hym-1B (75nmol/kg bw)

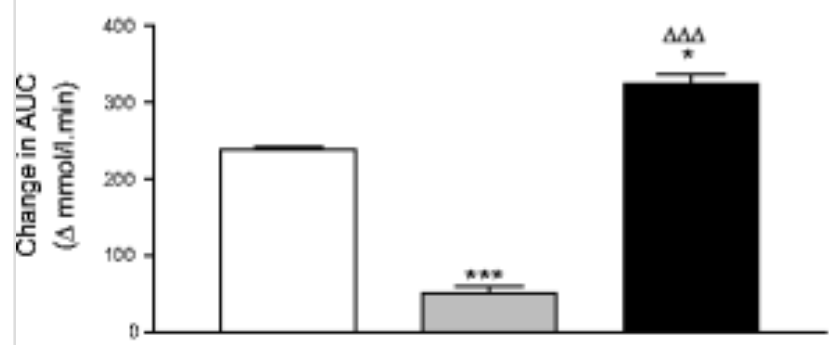

Integrated response
Plasma Insulin

(b)

$\square$ Lean Control (Saline)

$\square$ High Fat Control (Saline)

[P5K]hym-1B (75nmol/kg bw)

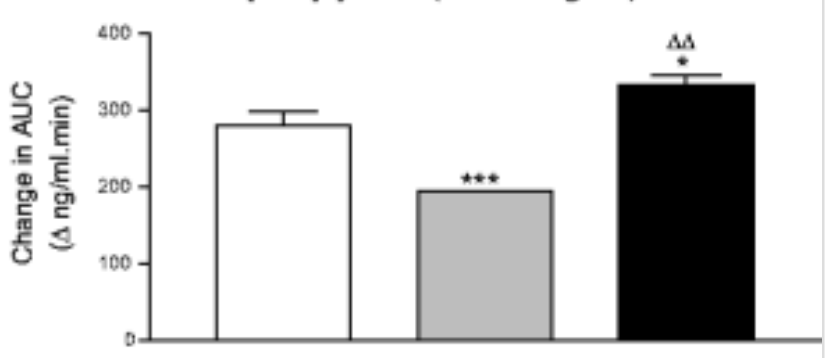

Integrated response 
Fig. 4

Effects of [P5K]hym-1B administration on insulin sensitivity in high-fat-fed mice. Blood samples were taken before and after intraperitoneal administration of insulin (25 U/kg body weight) in lean control, high-fat-fed control and $[\mathrm{P} 5 \mathrm{~K}]$ hym-1B-treated mice after 28 days. Values are means \pm S.E.M. $(n=6)$. The integrated glucose response (area under the curve, AUC) is shown in panel $\mathrm{b}$ and HOMA IR in panel c. ${ }^{* *} P<0.01 * * * P<0.001$ compared to lean mice. ${ }^{\Delta} P<0.05,{ }^{\Delta \Delta} P<0.01$ compared to high-fat-fed control mice

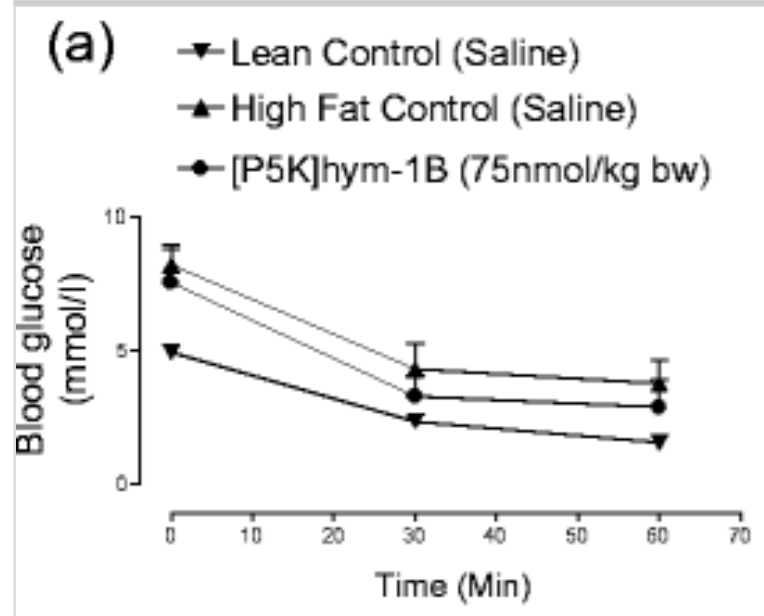

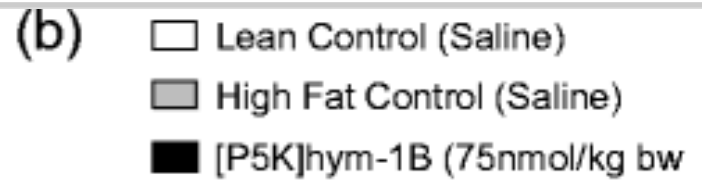

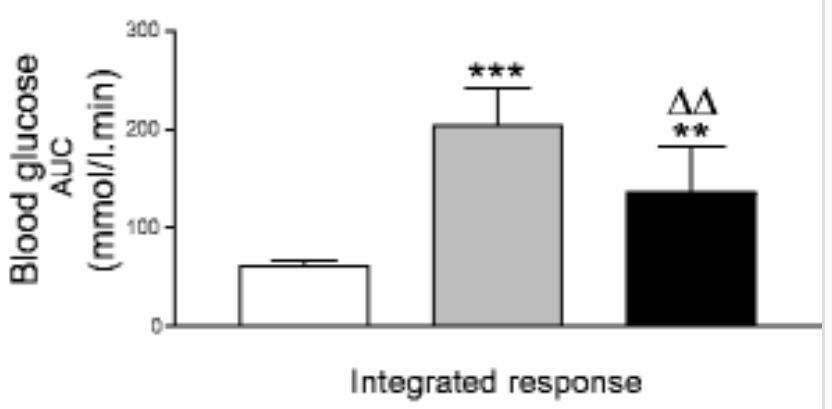

(c) $\square$ Lean Control (Saline)

$\square$ High Fat Control (Saline)

[P5K]hym-1B (75nmol/kg bw)

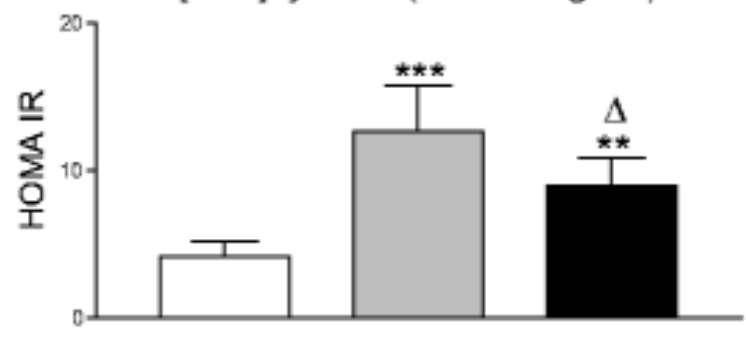

Integrated response

\section{Effects of $\left[\mathrm{P}_{5} \mathrm{~K}\right]$ hymenochirin-1B administration on} pancreatic weight, insulin content and islet secretory responses

No differences were found in pancreatic weight in the three groups but the insulin content was significantly $(P<0.05)$ increased in the high-fat-fed animals (Fig 5a) compared with lean controls. [P5K]hym-1B treatment produced a significant $(P<0.01)$ reduction in total insulin content compared 
to saline-treated high-fat-fed controls (Fig $5 \mathrm{~b}$ ). The insulin secretory responses to $16.7 \mathrm{mM}$ glucose and to the other secretogogues tested using islets isolated from high-fat-fed mice were significantly less than the responses of islets from lean mice. However, the magnitude of the responses of islets from [P5K]hym-1B-treated mice to all secretogogues, including GLP-1 and GIP, were significantly greater than those from high-fat animals indicating that the peptide had restored insulin secretion to the level observed in islets isolated from lean animals (Fig $5 \mathrm{c}$ ).

\section{Fig. 5}

Effects of [P5K]hym-1B administration on a pancreatic weight, $\mathbf{b}$ total insulin content, $\mathbf{c}$ islet insulin-secretory responses and expression of $\mathbf{d}$ GLP-1 receptor and e GIP receptor genes in islets isolated from high-fat-fed mice. Analysis were carried out using lean control, high-fat control and [P5K]hym-1B-treated mice after 28 days. For gene expression studies, $\beta$-actin was used as reference gene to which all mRNA concentrations (arbitrary units) are normalized. Values are means \pm S.E.M. $(n=4) .{ }^{*} P<0.05, * * P<0.01, * * * P<0.001$ compared with lean control mice. ${ }^{\Delta} P<0.05,{ }^{\Delta \Delta} P<0.01,{ }^{\Delta \Delta \Delta} P<0.001$ compared to highfat-fed control mice 


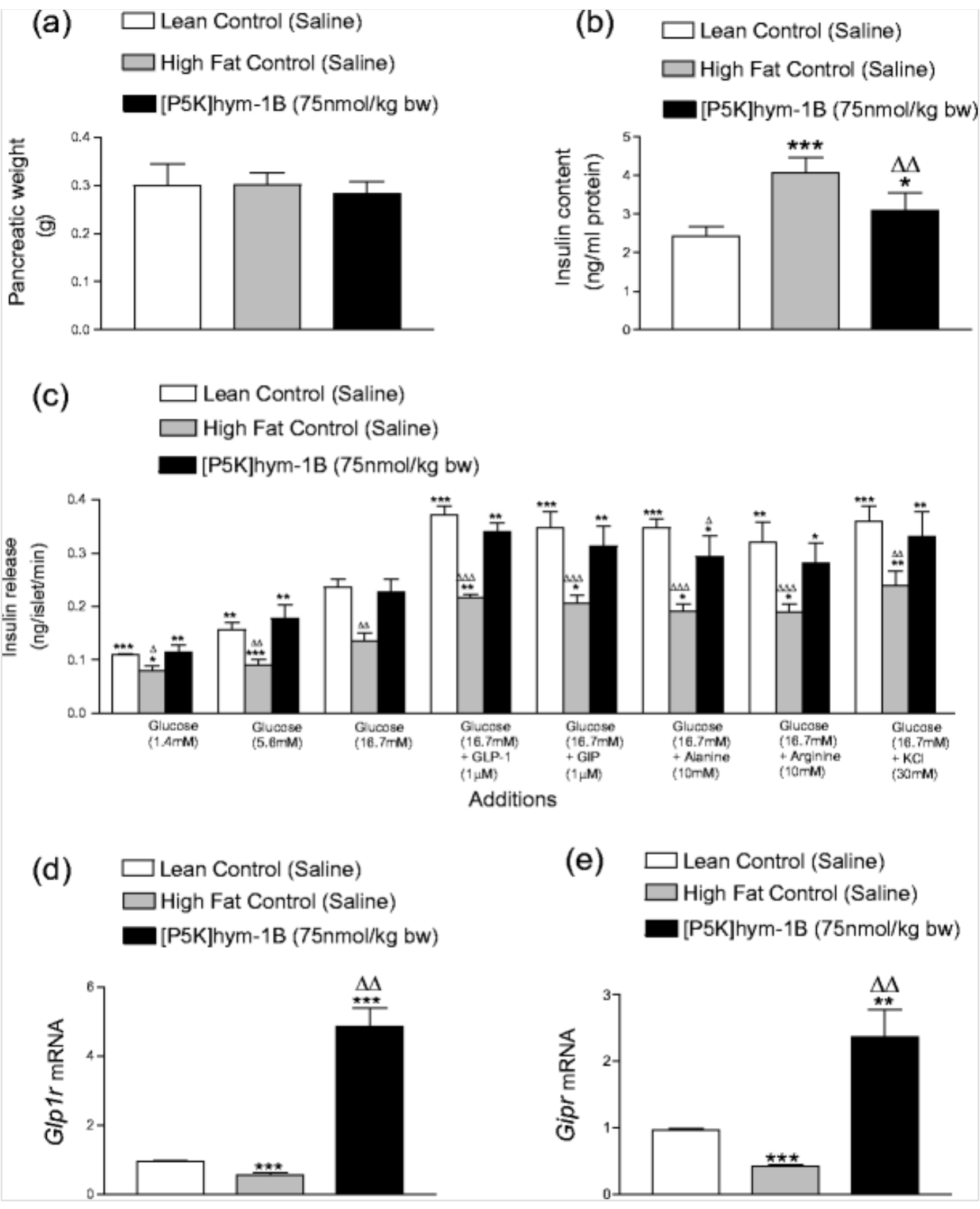

Effects of $\left[\mathrm{P}_{5} \mathrm{~K}\right]$ hym-1B administration on and glucagon concentrations and the plasma lipid and enzyme profiles

High-fat-fed mice showed significantly $(P<0.001)$ higher levels of glucagon in plasma (Fig. 6a) and the pancreas (Fig. 6b) compared to lean mice. $[\mathrm{P} 5 \mathrm{~K}]$ hym-1B administration significantly $(P<0.01)$ decreased both plasma 
and pancreatic glucagon concentrations compared with saline-treated, highfat-fed control mice. Plasma cholesterol concentrations were significantly $(P<0.05)$ increased in high-fat control animals. Significantly $(P<0.01)$ raised plasma triglyceride concentrations were observed in high-fat-fed untreated animals that was significantly $(P<0.01)$ lower in the [P5K]hym1B-treated group. Administration of the peptide also produced a significant $(P<0.01)$ increase in plasma HDL concentrations and a significant $(P<0.01)$ decrease in LDL concentrations compared with their untreated high-fat-fed mice (Fig. 6c). [P5K]hym-1B administration had no effect on plasma concentrations of amylase (Fig. $6 \mathrm{~d}$ ), AST and ALT but the plasma ALP concentration was significantly $(P<0.05)$ lower in high-fat-fed control mice compared to [P5K]hym-1B-treated animals (Fig. 6e). Plasma creatinine concentrations were significantly $(P<0.01)$ lower in $[\mathrm{P} 5 \mathrm{~K}]$ hym-1B-treated and lean control animals compared with the high-fat-fed control group (Fig. $6 \mathrm{e})$.

\section{Fig. 6}

Effects $[\mathrm{P} 5 \mathrm{~K}]$ hym-1B administration on a plasma glucagon, b pancreatic glucagon, $\mathbf{c}$ plasma lipid profile, $\mathbf{d}$ serum amylase concentrations and $\mathbf{e}$ plasma concentrations of enzymes in high-fat-fed mice. Analysis were carried out using lean control, high-fat control and $[\mathrm{P} 5 \mathrm{~K}]$ hym-1B-treated mice after 28 days. Values are means \pm S.E.M. $(n=6) .{ }^{*} P<0.05,{ }^{* *} P<0.01$, *** $P<0.001$ compared to lean control mice; ${ }^{\Delta} P<0.05,{ }^{\Delta \Delta} P<0.01$ compared to high-fat-fed control mice 
(a)

$\square$ Lean Control (Saline)

$\square$ High Fat Control (Saline)

[P5K]hym-1B (75nmol/kg bw)

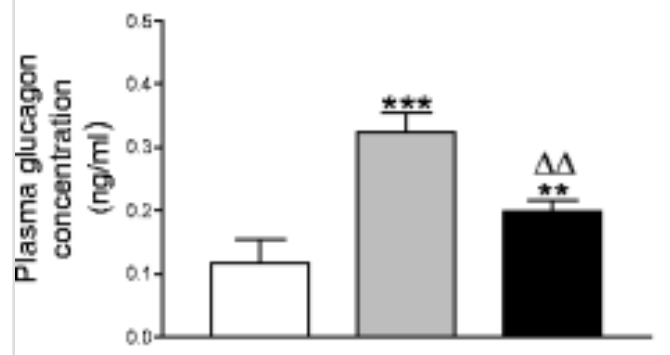

(c) $\square$ Lean Control (Saline)

$\square$ High Fat Control (Saline)

[P5K]hym-1B (75nmol/kg bw)

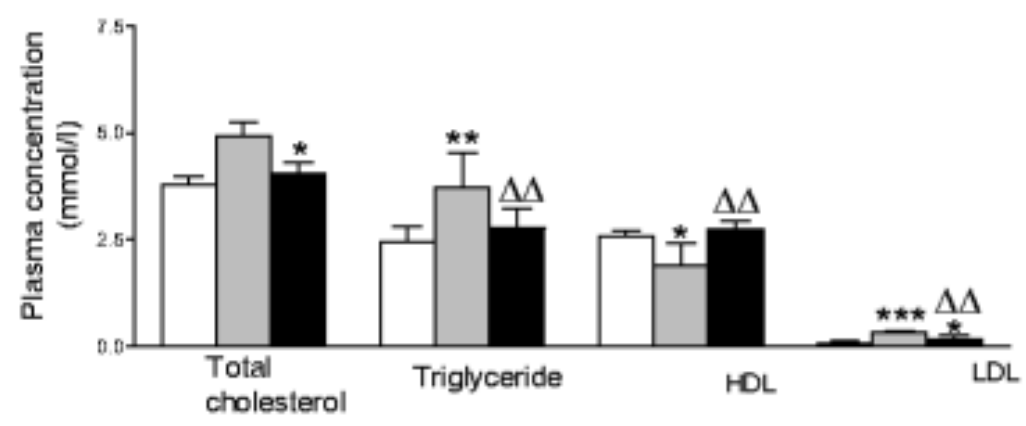

(e) $\square$ Lean Control (Saline)

$\square$ High Fat Control (Saline)

[P5K]hym-1B(75nmol/kg bw)

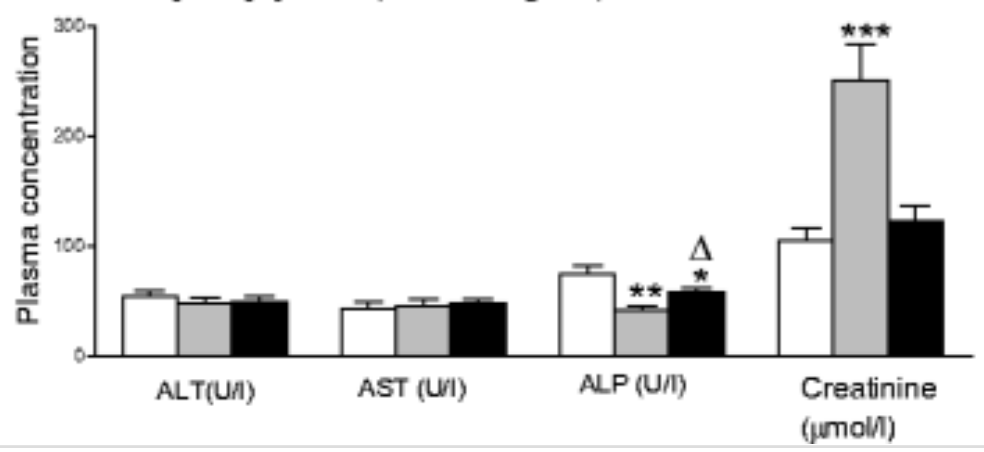

(b) $\square$ Lean Control (Saline)

High Fat Control (Saline)

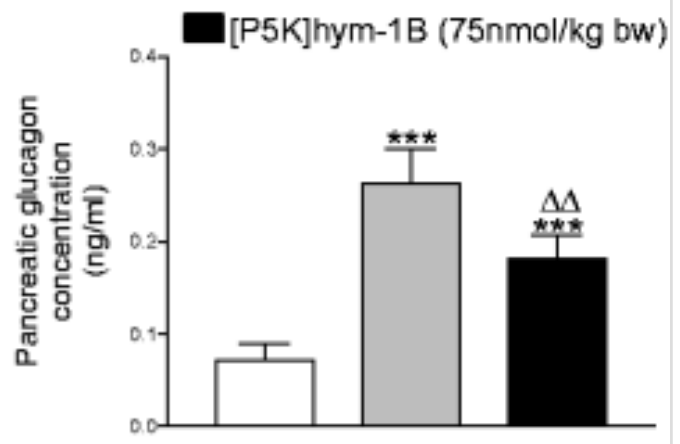

(d)

$\square$ Lean Control (Saline)

$\square$ High Fat Control (Saline)

[P5K]hym-1B (75nmol/kg bw)

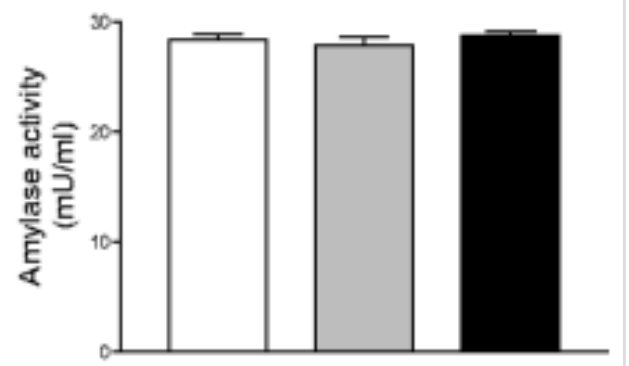

\section{Effects of $\left[\mathrm{P}_{5} \mathrm{~K}\right] \mathrm{hym}-1 \mathrm{~B}$ administration on islet cell morphology}

Representative images of islets showing $\beta$-cells (red) and $\alpha$-cells (green) from [P5K] hym-1B-treated, high-fat-fed control and lean control mice are shown in Fig. 7 a. Total islet area, $\beta$-cell area and $\alpha$-cell area were significantly $(P<0.001)$ increased in mice maintained on high-fat diet compared to lean controls. [P5K]hym-1B treatment did not produce any change in total islet numbers (Fig. 7b). However, peptide administration resulted in a significant 
$(P<0.01)$ reduction in islet area (Fig. $7 \mathrm{c}), \beta$-cell area (Fig. $7 \mathrm{~d})$ and $\alpha$-cell area (Fig. 7 e). Larger islet cells were seen in the high-fat-fed control group compared with the lean control and [P5K]hym-1B-treated groups (Fig. $7 \mathrm{f}$ ).

\section{Fig. 7}

Effects of [P5K]hym-1B administration on islet morphology in high-fat-fed mice. a Representative islets showing insulin (red) and glucagon (green) immunoreactivity from lean, high-fat-fed control and [P5K]hym-1B-treated mice at 28 days, $\mathbf{b}$ islet number, $\mathbf{c}$ islet area, $\mathbf{d} \beta$-cell area, $\mathbf{e} \alpha$-cell area and $\mathbf{f}$ islet size distribution. Data show means \pm S.E.M. $(n=6$; approximately 120 islets per group). $* P<0.05, * * * P<0.001$ compared with lean control group. ${ }^{\Delta} \mathrm{P}<0.01$ compared to high-fat-fed control group
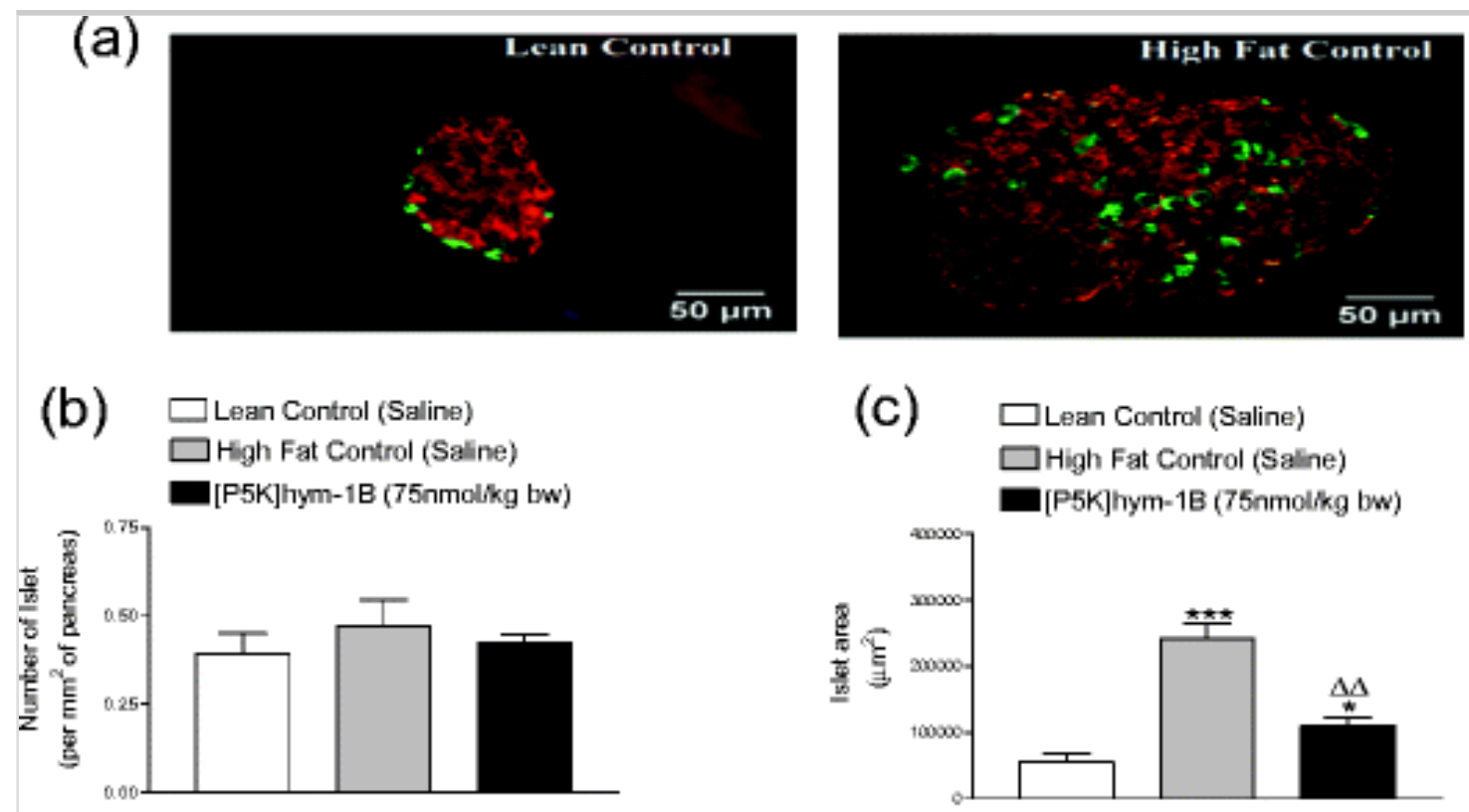

(e) $\square$ Lean Control (Salinee)

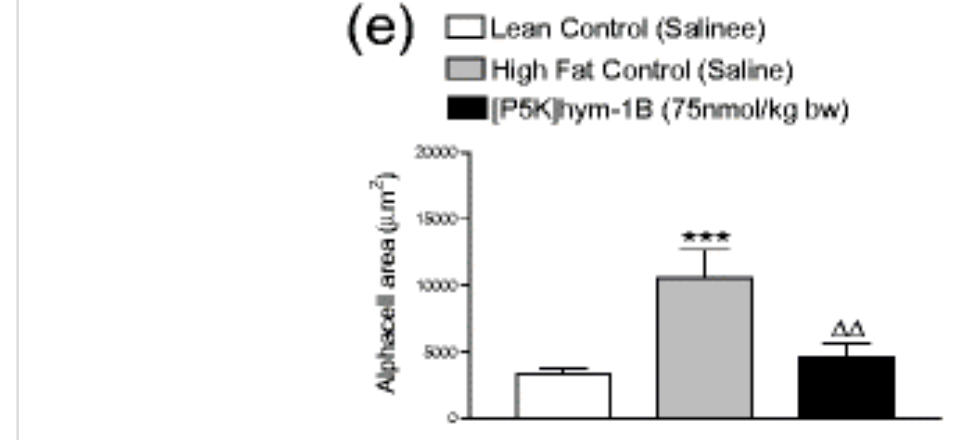

(f)
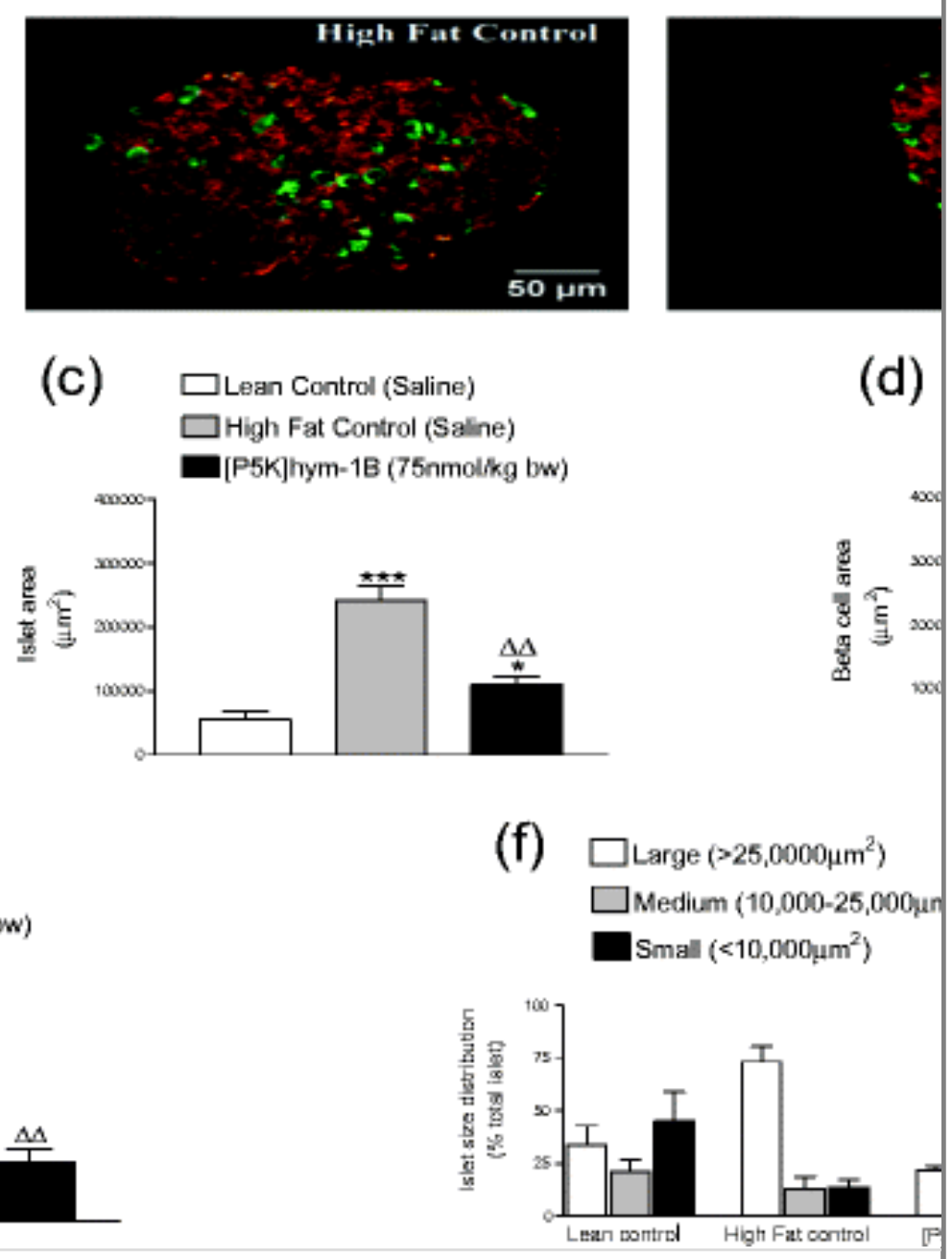

\section{Effects of $\left[\mathrm{P}_{5} \mathrm{~K}\right]$ hym-1B administration on selected gene expression in skeletal muscle and islets}

Feeding a high-fat diet to control mice resulted in significantly reduced 
skeletal muscle expression of the Slc2a4 (GLUT4), Insr (insulin receptor), Irs 1 (insulin receptor substrate 1), Akt1 (protein kinase B alpha), Pdkl (3phosphoinositide dependent protein kinase 1) and Pik3ca (phosphatidylinositol 3-kinase catalytic subunit $\alpha$ ) genes compared with lean mice (Fig. $8 \mathrm{e}-\mathrm{f}$ ). In contrast, expression of the Ptbl (protein phosphatase 1B) gene was significantly $(P<0.01)$ up-regulated in high-fat-fed control mice (Fig. $8 \mathrm{~g}$ ). Administration of [P5K]hym-1B enhanced Insr gene expression by $54 \%(P<0.01)$ compared with the high-fat-fed control group. Similar significant increases in the level of expression were found for the Slc2a 4 (60\%) Irs 1 (51\%), Pik3ca (65\%), Akt1 (48\%) and Pkd1 (41\%) genes. Expression of the $P t b 1$ gene was not significantly different between the highfat-fed animals treated with $[\mathrm{P} 5 \mathrm{~K}] \mathrm{hym}-1 \mathrm{~B}$ and those receiving saline. In islets, the glucagon-1-like peptide receptor (Glplr) (Fig 5d) and gastric inhibitory polypeptide receptor (Gipr) (Fig 5e) genes were down-regulated in the saline-treated high-fat-fed animals compared to lean controls. [P5K]hym1B administration significantly $(P<0.01)$ increased the expression of $\mathrm{Gipr}$ ( $82 \%$ ) and Glplr (88\%) genes compared to the high-fat-fed control group.

\section{Fig. 8}

Effects of [P5K]hym-1B administration on gene expression in skeletal muscle from high-fat-fed mice. Genes encoding the following proteins were studied in lean control, high-fat control and [P5K]hym-1B-treated mice after 28 days: a GLUT4 (Slc2a4), b insulin receptor (Insr), c insulin receptor substrate 1 (Irs1), d 3-phosphoinositide dependent protein kinase 1 ( $P d k 1)$, e protein kinase B $(A k t 1)$, f phosphatidylinositol 3-kinase, catalytic subunit $\alpha$ (Pik3ca) and $\mathbf{g}$ protein phosphatase 1B (Ptb1). $\beta$-actin was used as reference gene to which all mRNA concentrations (arbitrary units) are normalized. Values are means \pm S.E.M. $(n=4) .{ }^{* *} P<0.01,{ }^{* * *} P<0.001$ compared to lean control group; ${ }^{\Delta} P<0.05,{ }^{\Delta} P<0.01$ compared to high-fat-fed control group 


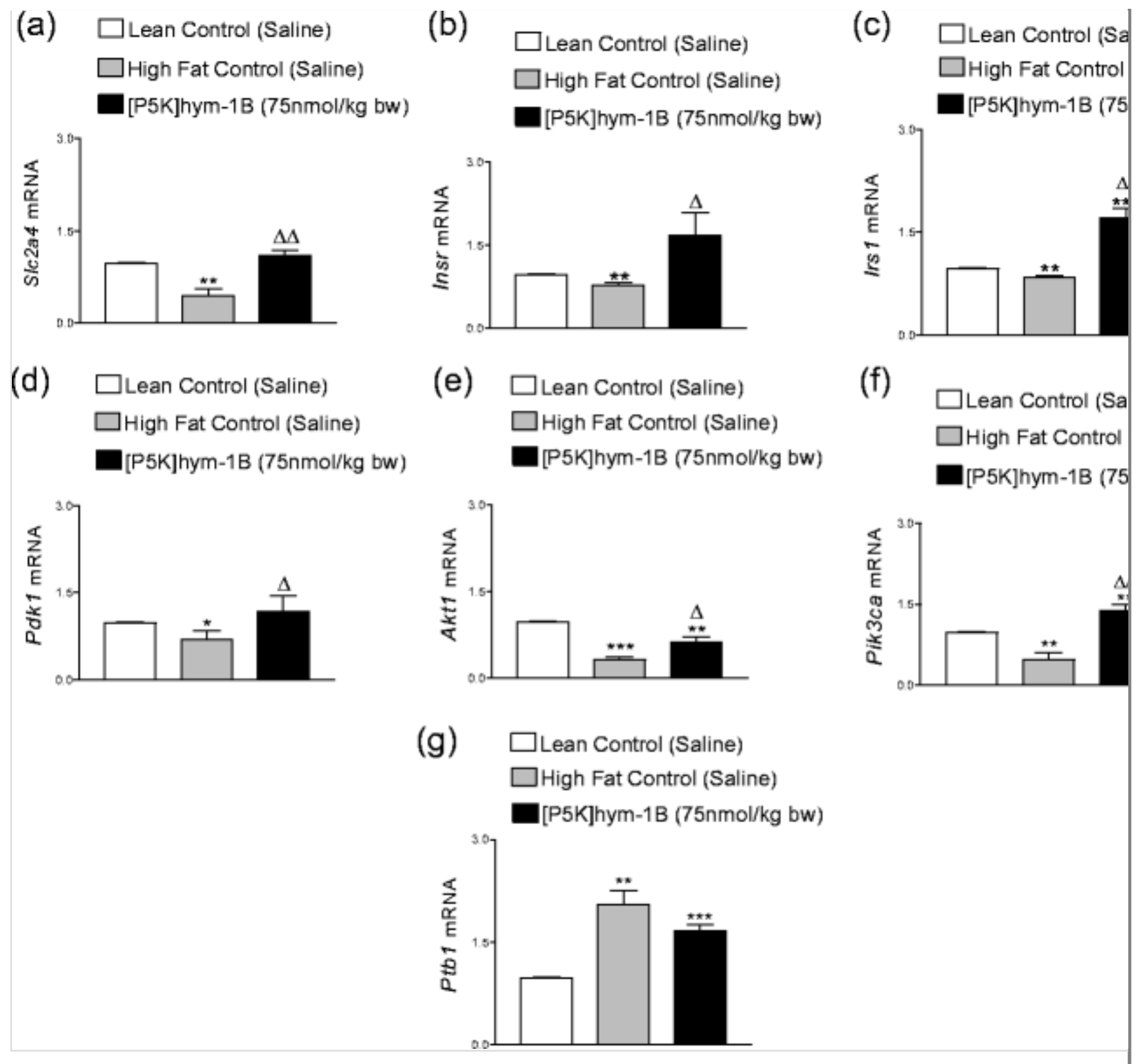

\section{Discussion}

Administration of [P5K]hym-1B over a 28-day period to high-fat-fed mice with insulin resistance and impaired $\beta$-cell function resulted in decreased circulating non-fasted glucose concentrations, improved oral and intraperitoneal glucose tolerance together with enhanced insulin secretion. In addition, peptide enhanced insulin sensitivity as indicated by improved glucose lowering actions of insulin and HOMA-IR. Clearly, these effects are inter-related and it is not entirely clear to what extent the beneficial effects of the peptide on glycaemic control are a result of increased insulin secretion or decreased insulin resistance. A previous in vitro study has demonstrated that 
[P5K]hym-1B significantly stimulates the rate of insulin release from dispersed mouse islets at a concentration as low as $0.1 \mathrm{nM}$ by a mechanism that involves an increase in intracellular cAMP. In line with this observation, down-regulation of PKA pathway by forskolin abolishes the insulinotropic activity of the peptide (Owolabi et al. 2016). In contrast to the action of some other other insulinotropic frog skin [reviewed in (Conlon et al. 2014)], the peptide did not block $\mathrm{K}_{\mathrm{ATP}}$ channels and depolarize the plasma membrane (Owolabi et al. 2016).

The mechanism by which the peptide decreases insulin resistance is a matter for speculation but it is unlikely that is exclusively a consequence of the reduced circulating glucose and alleviation of glucotoxicity resulting from increased insulin secretion. After this study was complete, a report appeared describing the beneficial effect on insulin sensitivity, without changes in body composition and weight, by treating high-fat-fed mice with an extract of the herb Urtica dioica (Obanda et al. 2016). Although the active component in the extract was not identified, it was shown that the decrease in insulin resistance was mediated by a reduction in protein phosphatase $2 \mathrm{~A}$ activity in skeletal muscle leading to a reduction in Akt (protein kinase B) dephosphorylation. The present study has demonstrated that [P5K]hym-1B administration produces changes in expression of genes in skeletal muscle as well as pancreatic islets. It is well-established that insulin resistance causes increased release of non-esterified fatty acids and high circulating concentrations of these components contribute to impaired insulin signalling and impaired glucose uptake in the skeletal muscle (Poletto et al. 2015). Activation of Glut4, Pi3k, Irs 1 and Akt are key steps in the signal transduction pathway culminating in insulin-induced glucose disposal. Activation of insulin receptor results in the recruitment and phosphorylation of a panel of substrate molecules of which Irs 1 serves as adapter molecule. Tyrosine phosphorylation of Irs 1 causes it to bind to the P85 regulatory subunit of Pi3k with subsequent generation of the second messenger phosphatidylinositol $(3,4,5)$-trisphosphate which in turn activates other molecules involved in insulin signalling such as $A k t$ and $P d k l$ (Fröjdö et al. 2009). This study has demonstrated down-regulation of the Pik3ca, Aktl, Irs 1, Insr and Slc2a4 genes in the skeletal muscle of insulin-resistant highfat-fed animals and that these genes were significantly up-regulated in these 
mice that were treated with $[\mathrm{P} 5 \mathrm{~K}]$ hym-1B. Although further studies are required to demonstrate parallel changes in protein concentration, phosphorylation and biological activity, it is plausible that the observed improvement in insulin sensitivity in peptide-treated mice involves, at least in part, enhanced insulin action in skeletal muscle.

Increased $\beta$-cell mass and enhanced insulin secretion are mechanisms by which the pancreas compensates for insulin resistance in order to maintain normoglycaemia (Mezza et al. 2014; Roat et al. 2014). Consistent with previous studies (Ojo et al. 2015b; Srinivasan et al. 2015), high-fat-fed mice exhibited significant increases in total islet area and in $\beta$ - and $\alpha$-cell areas compared to lean controls. Administration of [P5K]hym-1B significantly reduced both pancreatic insulin content and $\beta$-cell area. Unrestrained glucagon production resulting in circulating hyperglucagonaemia contributes to the observed hyperglycaemia in patients with type 2 diabetes (Cryer 2012). Treatment with [P5K]hym-1B resulted in decreased concentrations of glucagon in both pancreas and plasma and decreased $\alpha$-cell area which probably contributed to the observed lowering in plasma glucose concentrations during the study.

The incretin effect refers to the greater insulin response following an oral glucose compared with the same intravenous or intraperitoneal load (Kazakos 2011 ). In humans, this effect is mediated primarily by GLP-1 and GIP. Loss of the incretin effect is a specific and early characteristic of type 2 diabetes (Holst et al. 2011). Consistent with this, feeding a high-fat diet to mice decreased islet $\beta$-cell secretory responsiveness and impaired the incretin effect which was restored in animals treated with [P5K]hym-1B. Consistent with a previous study in obese and diabetic rats (Younan and Rashed 2007), feeding the high-fat diet resulted in down-regulation of the GIP receptor in islets but treatment with [P5K]hym-1B produced a marked increase in expression of the Gipr gene (Fig. 5d). The modest decrease in the expression of the Glp 1r gene seen in the high-fat-fed NIH Swiss mice in this study (Fig. $5 \mathrm{~d}$ ) was not seen in an earlier study with high-fat-fed obesity-prone inbred AKR/J mice (Imai et al. 2008) but this may simply be a strain difference. Previous work from the laboratory showed that several amphibian skin peptides stimulate the release of GLP-1 from GLUTag cells (Ojo et al. 2013). In particular, $[\mathrm{P} 5 \mathrm{~K}]$ hym-1B at $1-\mu \mathrm{M}$ concentration produces a significant 
increase in the rate of GLP-1 release from GLUTag cells (66 \% over basal rate) that is comparable to that produced by $10 \mathrm{mM}$ glutamine ( $76 \%$ over basal rate). This observation together with the major up-regulation of the GLP-1 receptor and the increased in vitro responses to GLP-1 in the islets of mice treated with $[\mathrm{P} 5 \mathrm{~K}]$ hym-1B compared with high-fat controls suggest that the restoration of the incretin effect may be mediated, at least in part, through increased release and efficacy of GLP-1 (Moffett et al. 2015). However, it should be noted that insulin sensitivity can also be increased indirectly by improving glycaemic control (Derosa et al. 2012).

Although long-term toxicological studies are needed, it is encouraging that animals receiving [P5K]hym-1B over 28 days showed no signs of distress or other adverse behavioural effects and that they maintained a high food intake. Furthermore, circulating concentrations of the hepatic marker enzymes ALT and AST, creatinine and amylase were similar to those of lean mice, suggesting that $[\mathrm{P} 5 \mathrm{~K}]$ hym-1B administration had no adverse effects on liver, kidney or exocrine pancreatic function. A number of clinically approved GLP-1 mimetics and dipeptidyl peptidase-4 inhibitors have been linked in some human and animal studies to pancreatic acinar cell injury (hypertrophy, autophagy, apoptosis, necrosis and atrophy) and duct changes, thereby raising safety concerns for increased risk of pancreatitis and pancreatic ductal metaplasia (Garg et al. 2010; Iyer et al. 2011; Rouse et al. 2014). Although the consensus opinion strongly favours continued use of these drugs, the situation illustrates the need for alternative therapeutic approaches. Concern has also been raised over induction of C-cell tumours of thyroid by GLP-1 mimetics (Nauck and Friedrich 2013 although such safety concerns have been minimized (Vangoitsenhoven et al. 2012). Clearly, future studies will also need to address questions such as the possibility that [P5K]hym-1B might provoke an allergic reaction in patients and be associated with nausea and adverse gastrointestinal side-effects as is sometimes found with GLP-1 receptor agonists (Østergaard et al. 2016).

\section{Conclusions}

This study has demonstrated that $[\mathrm{P} 5 \mathrm{~K}]$ hym-1B exhibits a diverse range of properties that indicate that it may have potential for development into a drug for treatment of patients with type 2 diabetes. Peptide treatment lowered 
circulating glucose concentrations and a previous study involving acute administration of [P5K]hym-1B to mice (Owolabi et al. 2016) did observe any "overshoot" leading to hypoglycaemia. In particular, the peptide is effective in overcoming insulin resistance and loss of the incretin effect that characterize the early stages of type 2 diabetes. Additionally, administration of the peptide reverses the abnormalities in $\beta$ - and $\alpha$-cell area and reduces hyperglucagonaemia. Metabolic syndrome is characterized by a cluster of factors that increase the risk of developing type 2 diabetes. These factors include central obesity, insulin resistance, elevated fasting concentrations of plasma glucose, triglycerides and LDL cholesterol concentrations, decreased HDL cholesterol concentrations and elevated blood pressure (O'Neill and O'Driscoll 2015). Although [P5K]hym-1B treatment had no significant effect on body weight, total fat or food intake during the duration of the study, the beneficial lowering of circulating triglyceride and LDL cholesterol concentrations and elevation of HDL cholesterol suggests that the peptide may be useful in preventing the progression of metabolic syndrome to diabetes. Future studies will investigate the effect of administration of hym$1 \mathrm{~b}$ analogues over an extended period of time on haemoglobin A1c concentrations.

Comparing their relative advantages and disadvantages as therapeutic agents, [P5K]hym-1B shares with GLP-1 analogues a glucose-dependent insulinotropic action that is mediated, least in part, through an increase in intracellular cAMP concentration. Both peptides also have the benefit of decreasing $\alpha$-cell area and post-prandial glucagon secretion. Unlike GLP-1 mimetics, [P5K]hym-1B does not appear to promote satiety and weight loss. GLP-1 receptor agonists retard gastric emptying and reduce hepatic glucose output but effects of [P5K]hym-1B on these parameters have not yet been studied. Our data suggest that [P5K]hym-1B may be superior to GLP-1 analogues with regard to improvements in insulin sensitivity and beneficial effects on circulating lipid and LDL/HDL concentrations. In view of the rapid clearance from the circulation of peptide-based therapeutic agents, it is unlikely that $[\mathrm{P} 5 \mathrm{~K}]$ hym-1B itself can be used to treat patients with Type 2 diabetes. In the case of drugs based upon the structure of GLP-1, this problem has been addressed by the design of analogues that incorporate a fatty acid moiety that facilitates binding to albumin and D-amino acids to increase 
stability to peptidases (Østergaard et al. 2016). This strategy will be employed to produce long-acting analogues of [P5K]hym-1B.

\section{Acknowledgments}

Funding for this study was provided by a project grant from Diabetes UK (grant number 12/0004457) and an award of a University Vice Chancellor Research Studentship to DKS.

Compliance with ethical standards

Conflict of interests The authors declare no conflict of interest.

\section{References}

Attoub S, Arafat H, Mechkarska M, Conlon JM (2013) Anti-tumour activities of the host-defense peptide hymenochirin-1B. Regul Pept $187: 51-56$

Cerf ME (2013) Beta cell dysfunction and insulin resistance. Front Endocrinol 4:1-12

Conlon JM, Mechkarska M, Lukic ML, Flatt PR (2014) Potential therapeutic applications of multifunctional host-defense peptides from frog skin as anti-cancer, anti-viral, immunomodulatory, and anti-diabetic agents. Peptides 57:67-77

Cryer PE (2012) Glucagon in the pathogenesis of hypoglycemia and hyperglycemia in diabetes. Endocrinology 153:1039-1048

Derosa G, Carbone A, D’Angelo A, Querci F, Fogari E, Cicero AF, Maffioli P (2012) A randomized, double-blind, placebo-controlled trial evaluating sitagliptin action on insulin resistance parameters and $\beta$-cell function. Expert Opin Pharmacother 13:2433-2442

Flatt PR, Bailey CJ (1981) Abnormal plasma glucose and insulin responses in heterozygous lean (ob/+) mice. Diabetologia 20:573-577 
Fröjdö S, Vidal H, Pirola L (2009) Alterations of insulin signaling in type 2 diabetes: a review of the current evidence from humans. Biochim Biophys Acta 1792:83-92

Garg R, Chen W, Pendergrass M (2010) Acute pancreatitis in type 2 diabetes treated with exenatide or sitagliptin. A retrospective observational pharmacy claims analysis. Diabetes Care 33:2349-2354

Global Burden of Disease Study 2013 (2015) Global, regional, and national incidence, prevalence, and years lived with disability for 301 acute and chronic diseases and injuries in 188 countries, 1990-2013: a systematic analysis for the global burden of disease study 2013. Lancet 386:743-800

Goto M, Maki T, Kiyoizumi T, Satomi S, Monaco AP (1985) An improved method for isolation of mouse pancreatic islets. Transplantation 40:437438

Holst JJ, Knop FK, Vilsboll T, Krarup T, Madsbad S (2011) Loss of incretin effect is a specific, important, and early characteristic of type 2 diabetes. Diabetes Care 34:S251-S257

Hull RL, Andrikopoulos S, Verchere CB, Vidal J, Wang F, Cnop M, Prigeon RL, Kahn SE (2003) Increased dietary fat promotes islet amyloid formation and $\beta$-cell secretory dysfunction in a transgenic mouse model of islet amyloid. Diabetes 52:372-379

Imai Y, Patel HR, Doliba NM, Matschinsky FM, Tobias JW, Ahima RS (2008) Analysis of gene expression in pancreatic islets from diet-induced obese mice. Physiol Genomics 36:43-51

Iyer S, Drake JA 3rd, West R, Mendez C, Tanenberg R (2011) Case report of acute necrotizing pancreatitis associated with combination treatment of sitagliptin and exenatide. Endocr Pract 18:e10-e13

Johnson R, McNutt P, MacMahon S, Robson R (1997) Use of the Friedewald formula to estimate LDL-cholesterol in patients with chronic 
renal failure on dialysis. Clin Chem 43:2183-2184

Kahn SE, Hull RL, Utzschneider KM (2006) Mechanisms linking obesity to insulin resistance and type 2 diabetes. Nature 444:840-846

Kazakos K (2011) Incretin effect: GLP-1, GIP, DPP4. Diabetes Res Clin Pract 93:S32-S36

Marshall JA, Bessesen DH (2002) Dietary fat and the development of type 2 diabetes. Diabetes Care 25:620-622

Martin CMA, Gault VA, McClean S, Flatt PR, Irwin N (2012)

Degradation, insulin secretion, glucose-lowering and GIP additive actions of palmitate-derivatised analogues of xenin-25. Biochem Pharmacol $84: 312-319$

Mechkarska M, Prajeep M, Coquet L, Leprince J, Jouenne T, Vaudry H, King JD, Conlon JM (2012) The hymenochirins: a family of host-defense peptides from the Congo dwarf clawed frog Hymenochirus boettgeri (Pipidae). Peptides 35:269-275

Mechkarska M, Prajeep M, Radosavljevic GD, Jovanovic IP, Al Baloushi A, Sonnevend A, Lukic ML, Conlon JM (2013) An analog of the hostdefense peptide hymenochirin-1B with potent broad-spectrum activity against multidrug-resistant bacteria and immunomodulatory properties. Peptides 50:153-159

Mezza T, Muscogiuri G, Sorice GP, Clemente G, Hu J, Pontecorvi A, Holst JJ, Giaccari A, Kulkarni RN (2014) Insulin resistance alters islet morphology in non-diabetic humans. Diabetes 63:995-1007

Moffett RC, Irwin N, Francis JM, Flatt PR (2013) Alterations of glucosedependent insulinotropic polypeptide and expression of genes involved in mammary gland and adipose tissue lipid metabolism during pregnancy and lactation. PLoS One 8:e78560

Moffett RC, Vasu S, Thorens B, Drucker DJ, Flatt PR (2014) Incretin 
receptor null mice reveal key role of GLP-1 but not GIP in pancreatic beta cell adaptation to pregnancy. PLoS One 9:e96863

Moffett RC, Patterson S, Irwin N, Flatt PR (2015) Positive effects of GLP1 receptor activation with liraglutide on pancreatic islet morphology and metabolic control in $\mathrm{C} 57 \mathrm{BL} / \mathrm{KsJ} \mathrm{db} / \mathrm{db}$ mice with degenerative diabetes. Diabetes Metab Res Rev 31:248-255

Nauck MA, Friedrich N (2013) Do GLP-1-based therapies increase cancer risk? Diabetes Care 36:S245-S252

Obanda DN, Ribnicky D, Yu Y, Stephens J, Cefalu WT (2016) An extract of Urtica dioica L. mitigates obesity induced insulin resistance in mice skeletal muscle via protein phosphatase 2 A (PP2A). Sci Rep 6:22222

Ojo OO, Conlon JM, Flatt PR, Abdel-Wahab YHA (2013) Frog skin peptides (tigerinin-1R, magainin-AM1, -AM2, CPF-AM1, and PGlaAM1) stimulate secretion of glucagon-like peptide 1 (GLP-1) by GLUTag cells. Biochem Biophys Res Commun 431:14-18

Ojo OO, Srinivasan DK, Owolabi BO, Conlon JM, Flatt PR, Abdel-Wahab YHA (2015a) Magainin-AM2 improves glucose homeostasis and beta cell function in high-fat fed mice. Biochim Biophys Acta 1850:80-87

Ojo OO, Srinivasan DK, Owolabi BO, Flatt PR, Abdel-Wahab YHA (2015b) Beneficial effects of tigerinin-1R on glucose homeostasis and beta cell function in mice with diet-induced obesity-diabetes. Biochimie 109:18-26

O’Neill S, O’Driscoll L (2015) Metabolic syndrome: a closer look at the growing epidemic and its associated pathologies. Obes Rev 16:1-12

Østergaard L, Frandsen CS, Madsbad S (2016) Treatment potential of the GLP-1 receptor agonists in type 2 diabetes mellitus: a review. Expert Rev Clin Pharmacol 9:241-265

Owolabi BO, Ojo OO, Srinivasan DK, Conlon JM, Flatt PR, Abdel-Wahab 
YHA (2016) In vitro and in vivo insulinotropic properties of the multifunctional frog skin peptide hymenochirin-1B: a structure-activity study. Amino Acids 48:535-547

Poletto AC, Furuya DT, David-Silva A, Ebersbach-Silva P, Santos CL, Correa-Giannella ML, Passarelli M, Machado UF (2015) Oleic and linoleic fatty acids downregulate Slc2a4/GLUT4 expression via NFKB and SREBP1 in skeletal muscle cells. Mol Cell Endocrinol 401:65-72

Roat R, Rao V, Doliba NM, Matschinsky FM, Tobias JW, Garcia E, Ahima RS, Imai Y (2014) Alterations of pancreatic islet structure, metabolism and gene expression in diet-induced obese C57BL/6 J mice. PLoS One 9:e86815

Rouse R, Xu L, Stewart S, Zhang J (2014) High fat diet and GLP-1 drugs induce pancreatic injury in mice. Toxicol Appl Pharmacol 276:104-114

Srinivasan DK, Ojo OO, Owolabi BO, Conlon JM, Flatt PR, Abdel-Wahab YHA (2015) The frog skin host-defense peptide CPF-SE1 improves glucose tolerance, insulin sensitivity and islet function and decreases plasma lipids in high-fat fed mice. Eur J Pharmacol 764:38-47

Turner N, Zeng XY, Osborne B, Rogers S, Ye JM (2016) Repurposing drugs to target the diabetes epidemic. Trends Pharmacol Sci in press 11:54 AQ2

Vangoitsenhoven R, Mathieu C, Van der Schueren B (2012) GLP1 and cancer: friend or foe? Endocr Relat Cancer 19:F77-F88

Weyer C, Funahashi T, Tanaka S, Hotta K, Matsuzawa Y, Pratley RE, Tataranni PA (2001) Hypoadiponectinemia in obesity and type 2 diabetes: close association with insulin resistance and hyperinsulinemia. J Clin Endocrinol Metab 86:1930-1935

Winzell MS, Ahren B (2004) The high-fat diet-fed mouse: a model for studying mechanisms and treatment of impaired glucose tolerance and type 2 diabetes. Diabetes 53:S215-S219 
Ye J (2013) Mechanisms of insulin resistance in obesity. Front Med 7:1424

Younan SM, Rashed LA (2007) Impairment of the insulinotropic effect of gastric inhibitory polypeptide (GIP) in obese and diabetic rats is related to the down-regulation of its pancreatic receptors. Gen Physiol Biophys 26:181-193 